\title{
Analisis Model Pembelajaran Langsung dalam Mengurangi Miskonsepsi pada Pembelajaran Fisika
}

\author{
Yunita $^{1}$, Nana $^{2}$ \\ ${ }^{1}$ Mahapeserta didik Program Studi Pendidikan Fisika, Universitas Siliwangi \\ ${ }^{2}$ Dosen Program Studi Pendidikan Fisika, Universtias Siliwangi \\ Universitas Siliwangi Tasikmalaya \\ *Email: yunitauni217@gmail.com
}

\begin{abstract}
The purpose of this paper is to analyze the direct learning model in reducing misconceptions in physics learning. This writing is motivated by the number of students who still have misconceptions in learning physics. For this reason, there needs to be an effort to reduce misconceptions in physics learning, one way is by applying a direct learning model. The method used in this paper is a literature study by reviewing some of the literature to be analyzed and made conclusions. The results of this paper indicate that the application of this direct learning model can be a solution in an effort to reduce misconceptions in physics learning. Because, the direct learning model emphasizes understanding the concept so as to reduce the occurrence of misconceptions. However, even though it is still teacher-centered, students are still given a problem that must be solved by themselves so that they will better understand the concept because they are looking for themselves and solving the problem independently.
\end{abstract}

Keywords : direct Insruction, misconceptions, Physics Learning

ABSTRAK: Tujuan penulisan ini untuk menganalisis model pembelajaran langsung dalam mengurangi miskonsepsi pada pembelajaran fisika. Penulisan ini dilatarbelakangi oleh banyaknya peserta didik yang masih terjadi miskonsepsi pada pembelajaran fisika. Untuk itu perlu ada upaya untuk mengurangi miskonsepsi pada pembelajaran fisika salah satu caranya dengan menerapkan model pembelajaran langsung. Metode yang digunakan dalam penulisan ini adalah studi kepustakaan dengan mengkaji beberapa literatur untuk dianalisis dan dibuat kesimpulan. Hasil penulisan ini menunjukkan bahwa penerapan model pelajaran langsung ini dapat menjadi solusi dalam upaya untuk mengurangi miskonsepsi pada pembelajaran fisika. Karena, model pembelajaran langsung menekankan pemahaman konsep sehingga mengurangi terjadinya miskonsepsi. Namun meskipun masih berpusat pada pengajar, peserta didik tetap diberi sebuah permasalahan yang harus dipecahkan sendiri sehingga akan lebih memahami konsep karena mencari sendiri dan memecahkan masalahnya secara mandiri. Kata Kunci : Model Pembelajaran Langsung, Miskonsepsi, Pembelajaran Fisika

\section{PENDAHULUAN}

Dalam proses pembelajaran, peserta didik selalu diarahkan dan dituntut untuk bisa memahami materi pembelajaran dengan sebaik-baiknya. Namun, faktanya selama 
proses pembelajaran berlangsung peserta didik tidak selalu menyerap dan memahami informasi yang telah disampaikan dengan sepenuhnya, terlebih lagi pada mata pelajaran Fisika yang memuat banyak konsep ilmiah dan dianggap sebagai sesuatu yang menakutkan bagi peserta didik. Hasil-hasil penelitian yang telah dilakukan dalam dua dasawarsa terakhir ini dalam bidang pengajaran fisika, menunjukkan bahwa salah satu sumber kesulitan utama dalam pelajaran fisika adalah akibat terjadinya kesalahan konsep atau miskonsepsi pada diri peserta didik (Van den Berg, 1991). Sehingga adakalanya apa yang dipahami peserta didik mengenai suatu konsep ilmiah sering kali berbeda dengan konsep yang dianut oleh para ahli fisika pada umumnya (Suparno, 2013). Ketidaksesuaian pemahaman konsep tersebut sering kali disebut sebagai miskonsepsi atau konsepalternatif.

Miskonsepsi yang terjadi pada peserta didik tidak terlepas oleh adanya penyebab atau sumber dari ketidaksesuaian konsep yang ada. Penyebab terjadinya miskonsepsi dapat disebabkan oleh beberapa sumber, yaitu dari diri peserta didik, pengajar, buku teks yang digunakan, konteks, dan cara mengajar pengajar (Suparno, 2013). Miskonsepsi ini muncul pada diri peserta didik dapat berasal dari pengalaman seharihari di alam sekitarnya. Sebelum mempelajari fisika, semua peserta didik telah mempunyai pengalaman dengan peristiwa-peristiwa fisika, misalnya benda jatuh bebas, aliran listrik, energi, tumbukan, dan lain-lain. Dengan pengalaman itu maka yang ada dibenak para peserta didik sudah terbentuk suatu dugaan dan teori sendiri mengenai peristiwa-peristiwa fisika tersebut, yang sudah tentu dugaan dan teori yang terbentuk tersebut belum tentu benar Dalam proses pembelajaran, peserta didik selalu diarahkan dan dituntut untuk bisa memahami materi pembelajaran dengan sebaik-baiknya. Namun, faktanya selama proses pembelajaran berlangsung peserta didik tidak selalu menyerap dan memahami informasi yang telah disampaikan dengan sepenuhnya, terlebih lagi pada mata pelajaran Fisika yang memuat banyak konsep ilmiah dan dianggap sebagai sesuatu yang menakutkan bagi peserta didik.

Sebagai seorang pengajar, tentu peran pengajar di sekolah juga sangan penting dalam pembelajaran. Pengajar dapat memberikan pengaruh besar dalam menyesuaikan konsep-konsep pembelajaran teutama pembelajaran fisika sehingga tidak terjadi miskonsepsi. Namun, pengajar juga memerlukan sebuah cara atau strategi yang perlu dilakukan dalam proses pembelajaran. Salah satu upaya yang dapat dilakukan yaitu dengan menerapkan model pembelajaran yang dinilai efektif dalam mengatasi permsalahan pembelajaran khususnya miskonsepsi. Secara garis besar penggunaan model juga harus fleksibel karena didasarkan pada situasi dan kondisi di sekolah dengan tujuan untuk merangsang daya kreatif peserta didik (Yu Je Lee, 2011: 93). Salah satu model pembelajaran yang dapat digunakan yaitu model pembelajaran langsung.

Menurut Kardi (2012) pembelajaran langsung merupakan suatu model pembelajaran dari pendekatan yang bersifat Teacher Center. Dalam menerapkan model pembelajaran langsung, pengajar harus mendemonstrasikan pengetahuan dan 
keterampilan yang akan dilatihkan kepada peserta didik secara bertahap (selangkah demi selangkah). Pembela jaran langsung tidak sama dengan metode ceramah, namun ceramah dan retsitasi (mengecek pemahaman dengan tanya jawab) berhubungan erat dengan model pembelajaran langsung.

Ciri-ciri model pengajaran langsung menurut Kardi dan Nur (2005): (1) Adanya tujuan pembela jaran dan pengaruh model pada peserta didik termasuk prosedur penilaian belajar, (2) Sintaks atau pola keseluruhan dan alur kegiatan pembelajaran, (3) Sistem pengelolahan dan lingkungan belajar model yang diperlukan agar kegiatan pembelajara tertentu dapat berlangsung dengan berhasil.

Menurut Kardi dan Nur (2005) dalam Trianto (2007) langkah-langkah pengajaran langsung meliputi tahapan: (a) Menyampaikan tujuan, (b) Menyiapkan peserta didik, (c) Persentasi dan demonstrasi, (d) Mencapai kejelasan, (e) Melakukan demonstrasi, (f) Mencapai pemahaman dan pengua saan, (g) Berlatih, (h) Memberikan latihan terbimbing, (i) Mengecek pemahaman dan memberikan umpan balik, (j) Memberikan kesempatan latihan mandiri.

Berdasarkan ciri-ciri serta langkah-langkah tersebut, diharapkan bahwa model pembelejaran langsung dapat mengurangi miskonsepsi pada pembelajaran fisika. Oleh karena itu, penulis tertarik untuk menganalisis model pembelajaran langsung dalam mengurangi miskonsepsi pada pembelajaran fisika. Maka disusunlah penelitan yang berjudul "Analisis Model Pembelajaran Langsung dalam Mengurangi Miskonsepsi pada Pembelajaran Fisika".

\section{METODE PENELITIAN}

Metode yang digunakan dalam artikel ini adalah studi literatur atau studi pustaka. Data dikumpulkan dan dianalisis disajikan dalam hasil dan pembahasan untuk menarik kesimpulan.

\section{HASIL DAN PEMBAHASAN}

\subsection{Model Pembelajaran}

\section{Langsung}

Model pembelajaran langsung adalah model pembelajaran yang menekankan pada penguasaan konsep dan/atau perubahan perilaku dengan mengutamakan pendekatan deduktif, dengan ciri-ciri sebagai berikut: (1) transformasi dan ketrampilan secara langsung; (2) pembelajaran berorientasi pada tujuan tertentu; (3) materi pembelajaran yang telah terstuktur; (4) lingkungan belajar yang telah terstruktur; dan (5) distruktur oleh guru.

Menurut Arends (1997) dalam Trianto (2011 : 41), model pengajaran langsung adalah salah satu pendekatan mengajar yang dirancang khusus untuk menunjang proses belajar peserta didik yang berkaitan dengan pengetahuan deklaratif dan pengetahuan prosedural yangterstruktur dengan baik, yang dapat diajarkan dengan pola kegiatan yang 
bertahap,selangkah demi selangkah, terstruktur, mengarahkan kegiatan para peserta didik, dan mempertahankan fokus pencapaian akademik.

Pada pengajaran langsung terdapat lima fase yang sangat penting. Sintaks modelpembelajaran langsung (Trianto, 2007 : 43) ada 5 fase yaitu fase 1 menyampaikan tujuan dan mempersiapkan peserta didik, fase 2 mendemonstrasikan pengetahuan dan keterampilan, fase 3 membimbing pelatihan, fase 4 mengecek pemahaman dan memberikan umpan balik, fase 5 memberikan kesempatan untuk pelatihan lanjutan dan penerapan.

Sabagaimana halnya pelaksanaan pembelajaran pada umumnya, dalam pelaksanaan pembelajaran langsung pengajar perlu mengetahui bagaimana teknik perencanaannya sehingga saat menerapkan model pembelajaran ini dapat sukses.Adapun pembahasan tentang aspek-aspek perencanaan model pembelajaran langsung menurut Trianto (2015) ini meliputi:

1) Merumuskan Tujuan

Menurut Mager tujuan pembelajaran khusus harus sangat spesifik.Tujuan yang ditulis dalam format mager dikenal sebagai tujuan perilaku.

2) Memilih Isi

Bagi pengajar pemula yang masih dalam proses penguasaan sepenuhnya materi ajar, disarankan agar memilih materi ajar mengacu pada GBPP kurikulum yang berlaku, dan buku ajar tertentu.

3) Melakukan Analisis Tugas

Analisis tugas ini adalah alat yang digunakan oleh pengajar untuk mengidentifikasi dengan presisi yang tinggi hakikatnya dari suatu keterampilan atau butir pengetahuan yang terstruktur dengan baik, yang akan diajarkan oleh pengajar

4) Merencanakan Waktu dan Ruang

Ada dua hal yang harus diperhatikan oleh pengajar:

- Memastikan bahwa waktu yang disediakan sepadan dengan bakatdan kemampuan peserta didik

- Memotifasi peserta didik agar mereka tetap melakukan tugas-tugasnyadengan perhatian yang optimal

\subsection{Miskonsepsi}

Ilmu Fisika yang sebagian besar bersifat abstrak dan memerlukan penalaran yang cukup tinggi, sehingga di dalam mempelajarinya menyulitkan peserta didik dalam menggambarkan kedalam bentuk yang sebenarnya, dalam memahami konsepkonsepnya serta dapat menjadi verbalisme, hafal kata-katanya tetapi tidak mengerti arti sebenarnya. Ketidakmampuan tersebut menimbulkan miskonsepsi bagi peserta didik dalam mempelajari konsep-konsep Fisika (Nana, 2018). Miskonsepsi didefinisikan sebagai kesalahan pemahaman yang mungkin terjadi selama atau sebagai hasil dari pengajaran yang baru saja diberikan, berlawanan dengan konsepsi- 
konsepsi ilmiah yang dibawa atau berkembang dalam waktu lama (Mosik, 2010). Van Den Berg (1991) menjelaskan bahwa miskonsepsi adalah pola berpikir yang konsisten pada suatu situasi atau masalah yang berbeda-beda tetapi pola berpikir itu salah. Atau dengan kata lain konsepsi peserta didik bertentangan dengan konsep fisikawan, biasanya menyangkut hubungan antarkonsep.

\subsection{Pembelajaran Fisika}

Pembelajaran adalah proses interaksi peserta didik dengan pendidik dan sumber belajar pada suatu lingkungan belajar. Pembelajaran merupakan bantuan yang diberikan pendidik agar dapat terjadi proses perolehan ilmu dan pengetahuan, penguasaan kemahiran dan tabiat, serta pembentukan sikap dan kepercayaan pada peserta didik. Dengan kata lain, pembelajaran adalah proses untuk membantu peserta didik agar dapat belajar dengan baik.

Fisika adalah sains atau ilmu alam yang mempelajari materi beserta gerak dan perilakunya dalam lingkup ruang dan waktu, bersamaan dengan konsep yang berkaitan seperti energi dan gaya. Salah satu ilmu sains paling dasar, tujuan utama fisika adalah memahami bagaimana alam semesta bekerja. Jadi, pembelajaran fisika adalah proses interaksi yang terjadi antara peserta didik dengan pendidik dengan pelajaran fisika pada suatu lingkungan belajar misalnya di sekolah.

Fisika merupakan mata pelajaran yang dapat menumbuhkan kemampuan pemecahan masalah peserta didik. Oleh karena itu, dalam pembelajaran fisika peserta didik dituntut untuk membangun dan menemukan sendiri pengetahuannya sehingga dapat memecahkan masalah fisika seperti pemahaman konsep fisika sehingga tidak terjadi miskonsepsi.

\subsection{Analisis Model Pembelajaran Langsung dalam Mengurangi Miskonsepsi pada Pembelajaran Fisika}

Salah satu masalah dalam proses pembelajaran fisika yaitu adanya kesalahan dalam pemahaman konsep atau miskonsepsi sehingga diperlukan upaya yang dapat mengurangi permasalahan tersebut. Salah satu cara yang dapat diupayakan yaitu dengan memberikan persoalan sehingga peserta didik dapat memecahkan masalah tersebut dengan memahami konsep yang relevan, namun dalam proses pembelajaran sebagai seorang pengajar tetap harus membimbing secara langsung peserta didik.

Dalam proses pembelajaran, pengajar dapat menggunakan sebuah model pembelajaran untuk menunjang keberhasilan mencapai tujuan pembelajaran. Salah satu model pembelajaran yang dapat mengurangi miskonsepsi yaitu model pembelajaran langsung, karena model pembelajaran langsung menekankan pada penguasaan konsep dan atau perubahan perilaku. Model pembelajaran langsung adalah model pembelajaran yang menggunakan dasar prinsip-prinsip behavioral yang dapat digunakan untuk menghentikan kebiasaan. Demikian hal nya dengan 
miskonsepsi yang menjadi kebiasaan peserta didik, maka pembelajaran langsung diharapkan menjadi solusi tepat bagi pelurusannya.

Model pembelajaran langsung adalah model pembelajaran yang menekankan pada penguasaan konsep dan/atau perubahan perilaku dengan mengutamakan pendekatan deduktif, sehingga penguasaan konsep peserta didik akan meningkat. Ini memungkinkan untuk mengurangi miskonsepsi pada peserta didik.

Oleh karena itu, penulis dapat menyimpulkan bahwa model pembelajaran langsung dinilai efektif dalam mengurangi miskonsepsi karena rangkaian pembelajaran dalam model pembelajaran lagsung dapat meningkatkan penguasaan konsep, salah satunya karena model ini masih berpusat pada guru, namun tidak membatasi pemahaman dan keterampilan peserta didik.

\section{PENUTUP}

Penerapan model pelajaran langsung ini dapat menjadi solusi dalam upaya untuk mengurangi miskonsepsi pada pembelajaran fisika. Karena, model pembelajaran langsung menekankan pemahaman konsep sehingga mengurangi terjadinya miskonsepsi. Namun meskipun masih berpusat pada pengajar, peserta didik tetap diberi sebuah permasalahan yang harus dipecahkan sendiri sehingga akan lebih memahami konsep karena mencari sendiri dan memecahkan masalahnya secara mandiri.

\section{UCAPAN TERIMA KASIH}

Terima kasih kepada semua pihak yang mendukung dan membantu dalam penyusunan artikel ini. Terima kasih kepada Dr. Nana, M.Pd. yang telah membimbing dalam penyusunan artikel ini.

\section{Daftar Pustaka}

Kristiawan, W., Hairida, H., \& Lestari, I. REMEDIASI MISKONSEPSI PESERTA DIDIK MELALUI PEMBELAJARAN LANGSUNG DISERTAI PETA KONSEP PADA MATERI PERHITUNGAN KIMIA KELAS X SMA NEGERI 1 SEKAYAM. Jurnal Pendidikan dan Pembelajaran Khatulistiwa, 8(3).

Lee, Y. J. (2011). A study on the effect of teaching innovation on learning effectiveness with learning satisfaction as a mediator. World Transactions on Engineering and Technology Education, 9 (2), 92-101.

Mosik., \& Maulana, P. (2010). Usaha Mengurangi terjadinya miskonsepsi fisika melalui pembelajaran dengan pendekatan konflik kognitif. Jurnal Pendidikan Fisika Indonesia. 6(1), 98-103.

Nana. (2006). Penggunaan Pendekatan Konflik Kognitif untuk Meremidiasi Miskonsepsi Pembelajaran Suhu dan Kalor. Surakarta : Universitas Sebelas Maret(UNS) 
Nana. (2018). Penerapan Model Creative Problem Solving sebagai Inovasi Pembelajaran di Sekolah Menengah Atas dalam Pembelajaran Fisika. Seminar Nasional Fisika dan Aplikasinya.

Trianto. (2007). Model-Model Pembelajaran Inovatif Berorientasi Konstruktivistik, Jakarta: Prestasi Pustaka

Trianto. (2009). Medesain Model Pembelajaran Inovatif- Progresif. Jakarta : Kencana Prenada Media Group

Trianto. (2015). Mendesain Model Pembelajaran Inovatif- Progresif-dan kontekstual. Jakarta : Kencana Prenada Media Group.

Van Den Berg, Euwe. (1991). Miskonsepsi Fisika dan Remediasi . Salatiga: Universitas Kristen Satya Wacana(UKSW) 